\title{
An Ethnographic Study of the Passover Night Tradition in the Pandemic Situation to Preserve Ideology and Harmonious Social Environment
}

\author{
Lidya Sartika D Putri*, Agus Subiyanto \\ Master Program in Linguistic, Diponegoro University, Semarang
}

\begin{abstract}
Christian is religion that was born in Judea (Palestine) around the $1^{\text {st }}$ century, believing in the life story of Jesus Christ. In the life story of Jesus there is a story about the atonement of human sins. Jesus was crucified to atone for the sins of men and then rose up. The resurrection was considered a victory and celebrated as the Passover. Since then, tradition of Passover has been known as the day of celebration of Liberation for Catholics. In this celebration, there are a series of events of communication. This research is motivated by religious traditions and culture which are often only considered a ceremony. This study aims to find out the communicative situations, communicative events and communicative acts of Passover Night celebration. This study uses a qualitative descriptive method with an ethnographic approach. The result shows that there are so many symbols or meanings from each part on the ceremony. The symbols and their meaning can be found from interviewing some experts and conducting a direct observation of the ceremony. However, in the pandemic situation, the ceremony is conducted online with some adjustments in order that ideological aspects and harmonious social environment can still be preserved.
\end{abstract}

\section{Introduction}

Religion is a belief system that regulates values, morals, and bridges one's relationship with God. Each religion has a narrative or symbol that becomes its own identity. In a sociological perspective, religion is not something that is doctrinal or ideological in nature, but also appears in tangible forms in daily life. In this context religion is often seen as part of culture [1]. According to Hofstede (1994) in Zakiah, there are four concepts in the manifestation of culture in general, namely: symbols, heroism, values and ritual activities. Symbols can be in the form of images, meaningful objects, words, or hand movements that can only be understood by group members in the culture concerned [2].

In Chatolics, there is a celebration of Tri Hari Suci which ends in the celebration of Holy Saturday or often called Passover Night. The faithful celebrate Passover to commemorate the resurrection of Jesus which is believed by Christians as a redeemer of human sins. The resurrection is interpreted as a victory, therefore celebrated. Passover for

* Corresponding author: lidyasartikalinguistik@gmail.com 
Catholics is human liberation day over the power of sin which causes the relationship between man and God to be severed. In the Passover night there are communication symbols both verbal and nonverbal. Verbal communication symbols can be in the form of utterances such as prayer verses while nonverbal symbols can be in the form of movements and equipment in the procession.

Hence, no one study has used the rituals of the Passover night as an object of study, it can be said that this study was the first to study the communication patterns in the Passover Night celebration with the ethnographic approach to communication. The pattern of communication that is formed in the implementation of Passover Night is a tradition that lives among Catholics. The existence series of events with some equipment as symbols that has various meanings. This procession goes down and down every year, but many people, especially Christians, do not really understand the meaning of the celebration. The main purpose of this research is to examine the communication patterns that exist in the celebration of the Passover Eve Celebration and describe the meanings of the speech used therein.

\section{Previous Studies}

Conducting this research, the author refers to several previous studies as references. The first study by Maifianti, it is about Kanuri Blang Ritual Communication as a Form of Togetherness of Farmers in Samatiga District, West Aceh Regency, Aceh Province. Kanuri Blang is a ritual of gratitude to the Creator in the farming community in the Aceh area which is carried out at the beginning of the growing season. The research aims to see the ritual communication that takes place among the peasant communities in the Aceh area in the Kanuri Blang ritual. To obtain maximum results in his research, researchers conducted research with qualitative methods and using ethnographic communication approaches [2].

This study uses J. W. Carey's communication theory in the book Communication As Culture, Essays and Media and Society and concludes that: (1) Ritual communication is understood as sharing, participating, gathering, arguing, and ownership of the same beliefs. Kanuri Blang is a ritual carried out to gather, share and participate, because the village community, especially farmers, try to carry out and attend Kanuri Blang. (2) Communication that occurs in ritual communication is not centred on the transfer of information, but rather prioritizes sharing about shared culture. Communication practices in Kanuri Blang only emphasize the sharing and togetherness. Information given when the speech was not given much attention can be conveyed properly or not, as evidenced by the absence of speech sessions in several villages. (3) The use of language in ritual communication is done verbally (Acehnese), and symbolic (using buffalo). (4) The selection of unique and distinctive symbols is one of the prominent features in ritual communication. Kanuri Blang has a distinctive symbol of communication, namely eating together and buffalo slaughter. (5) In ritual communication, the media is a message. The message delivered at Kanuri Blang was more meaningful than the message delivered at the BP3K counseling program [2].

The second study was conducted by Sirait, namely Communication Patterns on the Mangulosi Procession in Batak Toba Indigenous Marriage. This research uses communication theory and L.A. culture. Samovar and R.E. Porter in the book Cross Cultural Communication. This research was conducted with a qualitative method through the ethnographic communication approach. The results of the following research are as follows: (1) the behavior patterns of the Batak Toba people tend to be strong in customs even though they existed in the era of moderation. The following procession of mangulosi although complicated and long. (2) Batak Toba people have high values in responding to the mangulosi procession which is considered as part of the Batak Culture that must be 
preserved. (3) The behavior patterns of the Batak Toba people in responding to the mangulosi procession still believe that the ulos cloth will give abundant blessings to the bride and some have assumed that giving the ulos cloth is only a custom that must be preserved [3].

The third study was conducted by Awalia on the Tradition of Hari Raya Six in Bangkinang Sub-District Village. Hari Raya Six is a tradition practiced by Muslims after fasting for six days in Shawwal. In this tradition there are a series of communication, social and cultural behaviors in the Bangkinang language community, especially to strengthen relations between generations. This study aims to determine the communicative situation, communicative events and communicative actions of the sixth Ramadan Tradition in the Bangkinang District Island. This study uses a qualitative method with an ethnographic approach. The results of the study concluded that the communicative situation in the tradition of the sixth Ramadhan Traditions in Bangkinang Island illustrates the situation that allows everyone to interact before and after the sixth Ramadan celebration of each tradition, each year, including some preparations made. Communicative events include a whole set of components that make up communication, namely the genre or type of event, topic, purpose and function, settings, participants, message forms, message content, action sequences, interaction rules, and interpretation norms on the Sixth Ramadan tradition. While communicative actions describe all ongoing communication activities that are unique or distinctive from the tradition of the Sixth Ramadhan, namely when the pilgrimage of Bangkinang people from various social statuses, age groups and groups move together towards the cemetery in the District on the Island and the surrounding area to visit Bajambou tombs and meals at designated gathering places, such as inside and terrace mosques or other places (Rumah Tuo) [4].

\section{Theoretical Framework}

In this study, the authors use the theory of speech events which, according to Chaer [5], is a linguistic interaction in one or more forms of speech involving speakers and interlocutors, with one main speech, at a particular time, place and situation. Dell Hymes (via Chaer and Agustina: 1995) suggests that a speech event must fulfill 8 components; the first is setting and scene. Settings relating to time, place of speech occur, and the scene refers to the situation, time and psychological situation of the conversation.

Second is participants relating to the parties involved in the talks. The third is ends refer to the intent and purpose of speech. Then, act sequence refers to the form and content of utterances which are related to the words used, how they are used, and the relationship between what is said with the topic of conversation. Key refers to the tone, manner, and passion when a message is delivered. This can also be demonstrated by gestures and cues. Instrumentalities refer to the language path used, such as spoken, written languages. Norms of Interaction and Interaction refers to norms or rules of interaction. The last is genre, refers to the type of delivery, can be in the form of poetry, proverbs, prayers, etc.

\section{Research Method}

This research is a qualitative descriptive study. In this study the writer collected data using observation and interview methods, which were conducted online via YouTube live streaming to adjust the government regulations resulting from the pandemic situation occurring in the world. Fortunately, the writer got participated directly in the celebration of the Passover Night Eucharist at St. Yusup Church in previous years. With the experience and assessment conducted online, the speeches from the celebration were then transcribed. 
The author also conducted in-depth interviews with informants consisting of two Romo / Pastors, and two sons and daughters of the Altar. After the data collected in the form of a speech list, the authors sort the data. Data which if it is not in accordance with the purpose of the study will be separated. The method used is ethnographic communication that focuses on the object of research. Ethnography is often applied to explain the conditions of the people being investigated in written form. The next step is data analysis using the theory of SPEAKING speech event components. This was done so that in this study obtained communication patterns that are interwoven in the celebration of Passover Night.

\section{Results and Discussion}

Based on the results of research conducted by researchers in the field both direct observation of observations in celebration and interviews with informants, especially Romo who served as the leader of the celebration, there are several sub-events in the Passover Night Celebration. The sub-event is divided into four parts, namely the Light Ceremony, Liturgy of the Word, Baptist Liturgy and Liturgy of the Eucharist.

\subsection{Light Ceremony}

In the Light ceremony there is the blessing of fire, the blessing of the Passover Candle, followed by the candlelight procession which is usually carried out from the front of the church to the altar table, accompanied by the singing of the song of Light of Christ or Christ of the Light of the World.

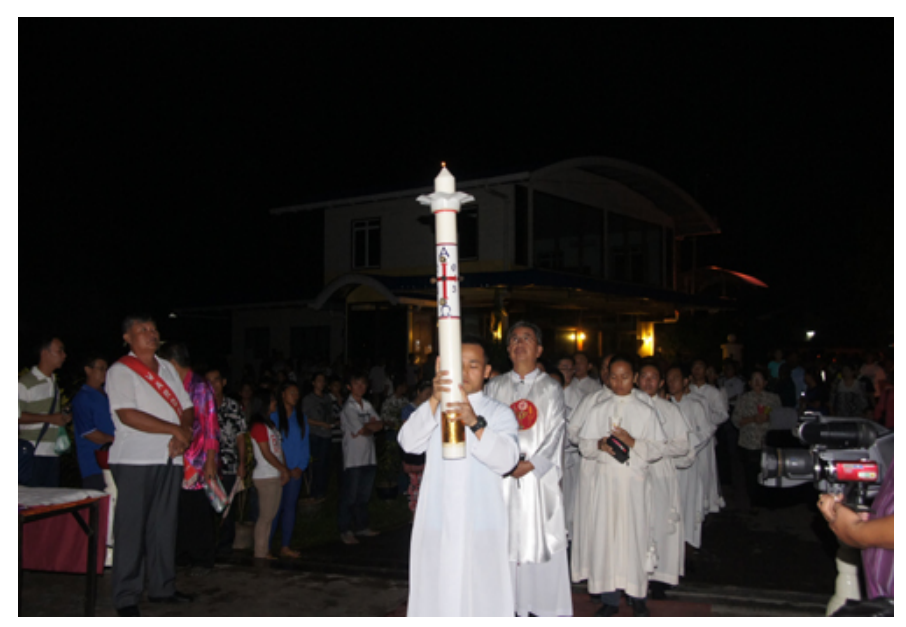

Fig. 1. Light Ceremony of Passover Night (Source: Private documentary) 


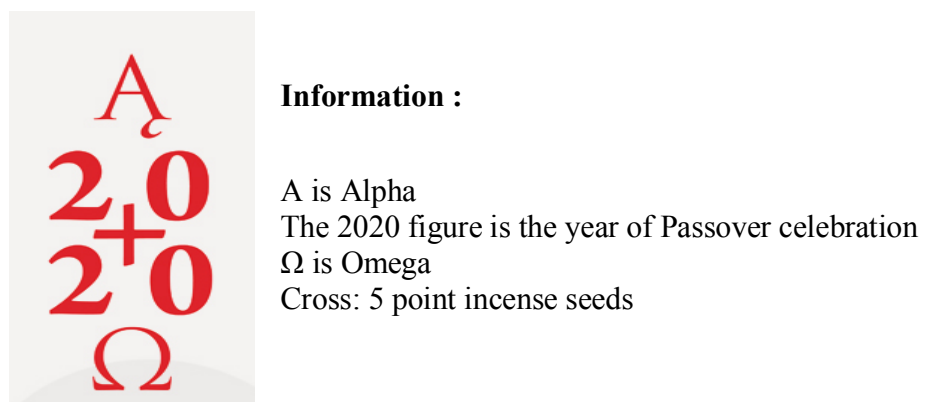

Fig. 2. Picture of the candle of Passover Night

In the Passover candle there are symbols that have a special meaning for the church (Figure 2). At the time of the blessing of the Post-Father's Candle as the leader of the celebration said: "Christ before and now, beginning and end, alpha and omega. He belongs to all ages and all ages, to Him is the glory and power of all ages. At the time of the light ceremony all the lights are turned off so that the atmosphere becomes dark which will return to light at the time of lighting the Passover Candle. Dark is a symbol of sin and death, while light is a symbol of victory or freedom. The Passover candle is likened to the light of the risen Christ. Therefore, people are asked to light candles with fire sourced from the Passover Candle.

The implied meanings in the Passover Candles are as follows:

1. The flame in the Post Candle symbolizes the resurrection of Christ and the atonement of man's sins.

2. Light Candles symbolize light that illuminates us in the dark.

3. The year symbolizes God who is present all the time with His people.

4. The cross is the symbol of Christ of the Light that guides our way. The Incense Seed symbolizes the five wounds on the Body of Christ. These five incense seeds are placed on the top, left, right, bottom and in the middle of the cross. These represent the five wounds of Jesus: three nails that pierced His hands and feet, a spear that pierced the stomach, and a thorn that pierced His head. In addition, these incense seeds also remind us of the aroma of spices applied to Jesus' body before he was buried.

5. Alpha and Omega means God is the beginning and also the end.

6. Picture The lamb symbolizes Christ as the perfect Passover lamb.

\subsection{Liturgy of Bible}

In the tradition of the Church, the proclamation of the word is conveyed consistently to the people at every Eucharistic celebration in the form of the Liturgy of the Word. Thus, it can be said that the Liturgy of the Word is a very important part of the celebration of the Eucharist. The Liturgy of the Word consists of the first reading, the response psalm, the second reading, the Alleluya / introductory verse of the Gospel, the reading of the Gospel, the acclamation after the Gospel, the homily, the creed of faith, and the prayer of the people. Given the importance of the Liturgy of the Word in the celebration of the Eucharist, each part will be explained in detail in this paper. The readings, contained in the celebration of Passover Night tell about the events of creation of nature and everything in it. In this ceremony Catholics are invited to give thanks and take care of God's creations. The existence of dark and light in the celebration of Passover Night is also intended so that 
humans can be a light for the environment, such as loving nature, caring for and making good use of God's creations and not being greedy.

\subsection{Baptist liturgy}

The baptismal liturgy during the celebration of the Passover Night is usually carried out to renew baptism promises for Catholics. In this event there were several prayers devoted to the saints and saints who were believed to be the protectors of the Catholics. There is also the blessing of holy water with Passover Candles; the water is used for blessings to remember the baptismal promises made by Catholics.

\subsection{The Eucharistic Liturgy}

The Liturgy of the Eucharist is the main worship service in the Catholic Church in which the sacrificed bread and wine change its substance into the presence of Christ [8]. The Eucharistic Liturgy consists of: Preparation of Offerings, Eucharistic Prayer, and Communion. The Eucharistic Prayer is a central part of a Eucharistic Celebration performed in each Eucharistic Celebration in the church in each parish (administrative territories within the Catholic Church in an area), in which in this procession Catholics glorify the work of God's salvation, led by a Catholic priest called 'Father'. Father is a Catholic leader in a parish, who has vowed to live in monastic life and has received special education and coronation from the Catholic Church to lead people. Therefore, only the Father is permitted by the Church to lead the Eucharist in which there is a procession of the Eucharistic Prayer. In this prayer the people are depicted as thanking Catholics for celebrating the Eucharist in fellowship with all the Churches in heaven and earth, life and death, and in fellowship with the Pope, the local diocesan / bishopric bishop, the priest, the deacon, and all believers. And with the end of the procession of the Community Prayer, the whole procession of the Eucharistic Prayer in a Eucharistic Celebration ends.

In the presentation of the sub-event above there is a communication component that acts as forming the communication event in celebration, namely: S (Situation Setting): Passover Eve celebrations occur once a year in the Catholic Churches. The above speeches occur in a formal, sacred atmosphere. So because in a sacred situation, all speeches are more centered on the priest (ritual leader), and for the people only follow, listen, and respond as needed.

P (Participant): Participants in the above speeches are Romo, and Catholics. The priest functions as a bridge between God and the Ummah, so that the priest plays more active role in the speech above because he plays the leader of the ceremony.

E (Ends): The purpose of the traditional communication of the Passover Eve Celebration above is to celebrate the Resurrection of Christ which is believed to be the redeemer of human SINS.

A (Act Sequence): The form of messages in the communication pattern of the celebration of Passover Night is a verbal message that contains prayers and hymns of Passover. In addition, there are also non-verbal messages through the tools and clothes used by the leader of the celebration. This is intended to be grateful for the work of God in human life that is extraordinary, and therefore the contents of the speech always glorify and glorify God.

$\mathrm{K}$ (Key): The tone in the utterances above tends to be a low tone, because to illustrate the humility of the people before how great the work of the Triune God.

I (Instrumentalities): The means of speech in communicating this Passover Eve celebration are oral languages that have specific guidelines set by the Church Council.

$\mathrm{N}$ (Norms): Communication in the celebration of the Passover Night which led to the appreciation of the event of human liberation from sin to become a better human being in 
life.

$\mathrm{G}$ (Genres): The types of speech events above are prayers to the Triune God, as a form of Catholic gratitude for the atonement and the resurrection of God.

\section{Communicative Situation of Passover Night Celebration}

The Passover Night celebration is a worship service in the Catholic Church that takes place after the Good Friday. According to the most ancient traditions, tonight is a night for God to celebrate the day of God's Resurrection, or more commonly called Passover Night. This holiday is held once a year but the date changes because it is adjusted to Sunday. Passover is usually celebrated between the end of March to the end or the beginning of April to the beginning of May, depending on the calendar agreed upon by the churches in the world. The Eucharistic is usually performed in a priest-centered church in the middle of the altar. On Passover night celebrations the church is usually filled with hundreds of Catholics which causes an increase of people inside the church. so that the church always prepares additional places, such as the utilization of buildings around the church, the right and left areas of the church are given chairs and additional screens or TVs connected directly to cameras around the church, especially in the altar area where the priest leads the celebration. However, the Passover Celebration in 2020 is different from previous years. The closure of the church by the government due to the corona virus pandemic caused people to have to celebrate Passover online, through live streaming YouTube at their respective homes. Even so, it does not reduce the solemn feeling that occurs at the celebration of Passover.

\section{Conclusions}

Based on the results of research and discussions that have been done about the communication acts of the tradition of the Passover Night Celebration to Catholics it can be concluded as that the communicative situation of the Catholic Passover Celebration tradition is conducted once a year which falls on Saturdays as the peak of the Tri Holy Day namely Holy Thursday, Good Friday then Holy Saturday (Passover Night). The communication patterns that occur in the celebration of Passover Night are one-way oral communication patterns, because they contain prayers, expressions of gratitude and exaltation of God's work, where the speech is frozen and cannot be replied directly by the people. However, there is still a two-way verbal communication pattern, when people respond to some of the utterances spoken by Romo, who acts as a bridge between the people and God. Communicative actions in the Passover Night Celebration have their own uniqueness or characteristics that will not be found on other celebration days, namely the procession and blessing of Passover Candles which have a height of 100-150 centimeters. 


\section{References}

1. Zazuli, M. Sejarah Agama Manusia. Yogyakarta: Narasi (2018)

2. K. Zakiah, Penelitian Etnografi Komunikasi : Tipe dan Metode, J. Komunikasi Mediator 9 (2008)

3. K.S. Maifianti, S. Sarwoprasodjo, D. Susanto, Komunikasi Ritual Kanuri Blang sebagai Bentuk Kebersamaan Masyarakat Tani Kecamatan Samatiga Kabupaten Aceh Barat Provinsi Aceh, J. Komunikasi Pembangunan 14 (2): 30-35 (2014)

4. Sirait, D.M., D. Hidayat, Pola Komunikasi pada Prosesi Mangulosi dalam Pernikahan Budaya Adat Batak Toba, J. Ilmu Komunikasi (2015)

5. G. Awalia, Etnografi Komunikasi Tradisi Hari Raya Enam di Kelurahan Kecamatan Bangkinang. J. JOM FISIP 6, (2019)

6. A. Chaer dan L. Agustina, Sosiolinguistik Perkenalan Awal, Jakarta: Rineka Cipta, (1995)

7. P. A. Andung, Komunikasi Ritual Natoni Masyarakat Adat Boti Dalam di Nusa Tenggara Timur, J. Ilmu Komunikasi. Hal. 36-43 (2014)

8. Keuskupan Agung Semarang, Buku Panduan Pekan Suci (1976) 